\title{
GLOBALISASI LESBIAN, GAY, BISEKSUAL, DAN TRANSGENDER (LGBT): PERSPEKTIF HAM DAN AGAMA DALAM LINGKUP HUKUM DI INDONESIA
}

\author{
Roby Yansyah, Rahayu \\ Program Studi Magister IImu Hukum \\ Fakultas Hukum Universitas Diponegoro \\ J I. Imam Bardjo, S.H. No. 1-3, Kampus Pleburan, Semarang 50241 \\ robyyansyah12@gmail.com
}

\begin{abstract}
Indonesia is a country upholding the religion's values strongly, therefore the deviant sexual behavior certainly could not be accepted. In addition, Indonesia is a country recognizing human rights, where LGBT (Lesby, Gay, Bisexual, and Transgender) peoples feel about experiencing the discriminations and human rights violations because of their sexual orientation. Meanwhile, sexual orientation is not specified in UDHR 1948 which became the UN's universal view of human rights. This research is a doctrinal research using qualitative juridical-normative law approach with descriptive-analytical method, to find secondary data in the form of prevailing legal norms of human rights and religious norms related to LGBT issue, and the obtained data were analyzed deductively from both perspectives, Human Rights and religion. Studies on LGBT issues on human rights and religion perspectives within the legal framework in Indonesia are conducted to obtain linkage as an opportunity to solve the problems arising from LGBT issues. Human rights are a recognized basic right in Indonesia, but there are some restrictions imposed by law, morals, ethics, and religious values affirming that every human being in addition to having his own human rights to be protected, he must also respect the rights of others as well public order around.
\end{abstract}

Keywords: Religion; Human Rights; Law; LGBT

\begin{abstract}
ABSTRAK
Indonesia adalah negara yang memegang teguh ajaran agama, sehingga perilaku seksual menyimpang tentu tidak dapat diterima begitu saja. Di sisi lain Indonesia merupakan negara yang mengakui HAM, di mana kaum LGBT (Lesbian, Gay, Biseksual, dan Transgender) merasa mengalami diskriminasi dan pelanggaran HAM karena orientasi seksual mereka yang menyimpang. Sementara itu, orientasi seksual sebenarnya tidak ditentukan dalam UDHR 1948 yang menjadi pandangan universal PBB terhadap HAM. Penelitian ini merupakan penelitian doktrinal dengan menggunakan pendekatan hukum yuridis-normatif yang bersifat kualitatif dengan metode deskriptif-analitis, untuk menemukan data sekunder berupa norma hukum HAM dan norma agama yang berlaku terkait dengan isu LGBT, kemudian menganalisa data tersebut secara deduktif dari kedua perspektif yakni HAM dan agama. Kajian mengenai isu LGBT perspektif HAM dan agama dalam lingkup hukum di wilayah Indonesia dilakukan agar didapatkan pertautan sebagai peluang untuk menyelesaikan permasalahan yang muncul dari isu LGBT. HAM adalah hak dasar yang diakui di Indonesia, akan tetapi ada pembatasan yang ditetapkan UU, moral, etika, dan nilai agama yang menegaskan bahwa setiap manusia di samping memiliki hak asasi manusia untuk dilindungi, mereka juga memiliki kewajiban untuk menghormati hak asasi orang lain dan juga ketertiban masyarakat sekitar.
\end{abstract}

Kata Kunci: Agama; HAM; Hukum; LGBT 
Jurnal Law Reform

Volume 14, Nomor 1, Tahun 2018

\section{A. Pendahuluan \\ 1. Latar Belakang}

Perilaku seksual yang menyimpang masih merupakan hal yang tabu bagi masyarakat Indonesia yang berbudaya ketimuran, masyarakat masih kental dan memegang teguh apa yang dinamakan dengan ajaran moral, etika, dan agama, sehingga perilaku seksual yang menyimpang tentu bukanlah fenomena yang dapat diterima begitu saja.

Perilaku seksual yang menyimpang itu sendiri, muncul atas dasar orientasi seksual yang menyimpang. Orientasi seksual adalah kecenderungan seseorang untuk mengarahkan rasa ketertarikan, romantisme, emosional, dan seksualnya kepada pria, wanita, atau kombinasi keduanya (Douglas, Markus, 2015). Perilaku seksual meyimpang dilakukan oleh kelompokkelompok orang yang memiliki orientasi seksual menyimpang, atau lebih dikenal dengan istilah kelompok LGBT (Lesbian, Gay, Bisexual, dan Transgender(Transsexual).

LGBT adalah istilah yang digunakan sejak tahun 1990-an (Sinyo, 2014), menggantikan frasa "komunitas gay" karena istilah ini dinilai lebih mewakili kelompok-kelompok yang "mengisi" istilah tersebut secara lebih rinci. LGBT terdiri dari kelompok: 1) Lesbi: kelompok wanita yang secara secara fisik, emosional, dan/atau spiritual merasa tertarik dengan wanita lain; 2) Gay: kelompok pria yang secara fisik, emosional, dan/atau spiritual merasa tertarik dengan pria lain; 3) Biseksual: kelompok orang yang secara fisik, emosional,
Program Studi Magister Ilmu Hukum Fakultas Hukum Universitas Diponegoro

dan/atau spiritual merasa tertarik baik kepada lawan jenis dan sesama jenis; 4) Transgender: kelompok orang yang merasa identitas gendernya berbeda dengan anatomi kelamin yang dimiliki, sehingga memilih/tidak memilih untuk melakukan operasi kelamin menyesuaikan dengan identitas gender yang diinginkan (APA: American Psychological Association, 2015).

LGBT sebenarnya bukanlah hal yang baru di negeri ini. Sebelumnya, telah banyak pertemuan penting dilakukan untuk mengakomodir kepentingan komunitas LGBT, terutama dalam menanggapi pelanggaran hakhak mereka sebagai komunitas seksual minoritas. Pada tahun 2006, diadakan perkumpulan di Yogyakarta yang pada akhirnya melahirkan "Prinsip Yogyakarta tentang Penerapan Hukum Hak Asasi Manusia Internasional yang Berkaitan dengan Orientasi Seksual dan Identitas Gender." Prinsip-prinsip tersebut menekankan perlindungan hak-hak komunitas seksual minoritas dan menciptakan kerangka kerja bagi standar hak asasi manusia internasional untuk masyarakat yang memiliki orientasi seksual dan identitas gender khusus (Onapajo, Isike, 2016).

Banyak kajian yang dilakukan oleh para akademisi dan aktivis HAM yang menghasilkan polarisasi sikap terhadap kaum LGBT. Banyak pihak yang menolak perilaku seksual menyimpang tersebut dan tidak sedikit pula yang bersedia menerima. Perdebatan pendapat antara keduanya semakin memanas dan meluas dengan adanya argumentasi-argumentasi yang 
Jurnal Law Reform

Volume 14, Nomor 1, Tahun 2018

berperspektif HAM dan argumentasi yang berperspektif agama.

Mereka yang pro terhadap perilaku seksual yang menyimpang, kerap menjadikan HAM sebagai perisai untuk melindungi kepentingan kaum LGBT. Bahwasanya mereka adalah manusia yang juga memiliki hak dan kesempatan yang sama dan tidak boleh diperlakukan secara diskriminatif (mengkriminalisasi orientasi seksual mereka). Di sisi lain, Indonesia adalah negara yang berke-Tuhanan, sebagai negara yang mengakui adanya Tuhan, warga negaranya diberi kebebasan untuk melaksanakan perintah Tuhan sebagaimana yang termaktub dalam kitab suci dan ajaran agama masing-masing. Berdasarkan pada ajaran agama-agama yang diakui di Indonesia, tidak terdapat alasan pembenar yang dapat dijadikan dalil untuk membenarkan perilaku seksual menyimpang kaum LGBT.

Berdasarkan uraian di atas, sistem hukum di Indonesia mengakui "konsep" HAM dan agama, sehingga perlu dikaji seperti apa pandangan hakhak kaum LGBT dari perspektif HAM, seperti apa pandangan hak-hak kaum LGBT dari perspektif agama, dan bagaimana hukum di Indonesia mengatur perilaku seksual menyimpang berdasarkan kepentingan perlindungan HAM dan penghormatan agama.

\section{Tujuan Penelitian}

Jurnal ini mengkritisi perilaku seksual menyimpang dilihat dari kedua perspektif yang "tampak" berseberangan yakni HAM dan agama dalam menghadapi isu LGBT, baik dalam ruang
Program Studi Magister Ilmu Hukum Fakultas Hukum Universitas Diponegoro

lingkup hukum nasional maupun hukum internasional yang berlaku dan diakui di Indonesia. Hasil dari kajian ini diharapkan dapat menemukan titik taut yang mengkomodir kepentingan HAM dan agama dalam lingkup hukum yang berlaku di Indonesia dalam memandang perilaku seksual yang menyimpang dari kaum LGBT

\section{Metode Penelitian}

Penelitian ini merupakan penelitian doktrinal dengan menggunakan pendekatan hukum yuridis-normatif terkait dengan perlindungan, pemenuhan, dan penghormatan terhadap HAM dan agama di Indonesia, serta mempertimbangkan ketentuan hukum normatif tersebut dalam kaitannya dengan perilaku seksual menyimpang kaum LGBT. Penelitian ini bersifat kualitatif karena mengandalkan kedalaman data dengan metode deskriptif-analitis. Data yang digunakan dalam penelitian ini adalah data sekunder berupa bahan-bahan hukum peraturan perundang-undangan, dokumen, buku, kamus, dan litelatur lain yang berkenaan dengan permasalahan yang akan dibahas. Metode analisis yang dipergunakan dalam penelitian ini adalah metode deduktif, dimulai dengan mendeskripsikan materi isi dan keabsahan data yang diperoleh dari hasil studi pustaka sehingga diperoleh gambaran fakta yang terjadi di masyarakat, dalam hal ini tentang hak-hak kaum LGBT dari perspektif HAM, hak-hak kaum LGBT dari perspektif agama, dan bagaimana hukum di Indonesia mengatur perilaku seksual 
Jurnal Law Reform

Volume 14, Nomor 1, Tahun 2018

menyimpang berdasarkan kepentingan perlindungan HAM dan penghormatan agama. Bertolak dari data yang didapatkan, permasalahan akan dipaparkan dan dianalisis dengan berlandaskan teori-teori/asas-asas hukum sehingga memperoleh kesimpulan yang komprehensif dan objektif atas permasalahan yang menjadi fokus penelitian.

\section{B. Pembahasan}

\section{Globalisasi LGBT dan Perkembangan nya di Indonesia}

Isu mengenai LGBT saat ini sudah berada pada tatanan global, keberhasilan penyebarannya dicapai melalui serangkaian gerakan pro-LGBT yang telah ada sejak lama. Fenomena ini didukung dengan adanya deklarasi HAM universal (Universal Declaration of Human Rights) pada tahun 1948, serta reformasi politik dan demokratisasi yang sering "disalahpahami" sebagai proses liberalisasi dan kebebasan mengekspresikan diri. Secara keseluruhan, semakin makmur dan sekuler suatu bangsa, maka semakin besar kemungkinannya untuk merangkul hak-hak kaum LGBT. Sebaliknya, semakin miskin dan religius suatu bangsa, maka semakin besar kemungkinannya untuk menekan kaum LGBT. Terutama dari fakta bahwa negara itu demokratis atau tidak, meskipun hak LGBT tidak ditemukan di semua negara yang demokratis, hak LGBT hampir tidak ada dalam negara non-demokrasi (Encarnacion, 2014).

Reformasi politik dan demokratisasi yang terjadi di Indonesia telah membawa isu LGBT
Program Studi Magister Ilmu Hukum Fakultas Hukum Universitas Diponegoro

menjadi sorotan yang menyebabkan berkembangnya organisasi LGBT. Berdasarkan sejarah, sekitar tahun 1968 istilah "Wadam" (Wanita Adam) muncul sebagai istilah yang lebih positif untuk menggantikan istilah homoseksual. Pada tahun 1969, organisasi Wadam pertama, Himpunan Wadam Djakarta (HIWAD) didirikan dengan difasilitasi oleh Gubernur Jakarta, Ali Sadikin. Istilah "Wadam" berubah menjadi Waria (Wanita Pria) pada tahun 1980 karena adanya keberatan dari beberapa pihak bahwa istilah "Wadam" tidak sopan karena mengandung nama nabi Adam AS (Muthmainnah, 2016). Disusul pada tanggal 1 Maret 1982, Lambda didirikan sebagai organisasi gay yang pertama di Indonesia dan Asia yang sekretariatnya bertempat di Solo. Pada tahun 1985, sebuah kelompok gay di Yogyakarta mendirikan Persaudaraan Gay Yogyakarta (PGY). Pada tanggal 1 Agustus 1987, Kelompok Kerja Wanita Lesbian dan Gay Nusantara (KKLGN) yang kemudian disingkat menjadi GAY NUSANTARA (GN) didirikan di Pasuruan, Surabaya, sebagai penerus Lambda. Pada bulan Desember 1993, diadakan Kongres Lesbian \& Gay Indonesia pertama (KLGI) di Kaliurang, di wilayah utara Yogyakarta, kongres tersebut menghasilkan 6 poin ideologis untuk arah masa depan gerakan gay dan lesbian dalam bahasa Indonesia (Muthmainnah, 2016).

Setelah adanya UDHR 1948, banyak kelompok masyarakat yang membuat langkah signifikan dalam mengadvokasi hak asasi 
Jurnal Law Reform

Volume 14, Nomor 1, Tahun 2018

manusia, tidak terkecuali kaum LGBT. Mereka berusaha untuk mendapatkan penerimaan universal dari masyarakat dunia. Di beberapa negara, kampanye hak LGBT banyak yang dibingkai sebagai bagian dari perjuangan untuk hak asasi manusia yang diakui secara internasional (Encarnacion, 2014). Fakta bahwa UDHR 1948 tidak secara khusus menentukan orientasi seksual kepada lawan jenis, memungkinkan hak LGBT dalam mengekspresikan orinetasi seksual mereka menjadi hal yang masih dapat diperdebatkan. Lebih jauh lagi, sebenarnya UDHR 1948 sama sekali tidak menyebutkan hal-hal mengenai orientasi seksual, hanya beberapa pasal yang menyangkut hak manusia untuk menikah dan membangun keluarga, namun pasal tersebut dapat dijadikan dasar sebab pernikahan merupakan cara legal dalam mengekspresikan orientasi seksual dan menjadi tujuan akhir bagi pasangan, terutama mengingat hukum dan kultur budaya di Indonesia. Pasal 16 UDHR 1948 menyatakan bahwa:

(1) Men and women of full age, without any limitation due to race, nationality or religion, have the right to marry and to found a family. They are entitled to equal rights as to marriage, during marriage and at its dissolution; (2) Marriage shall be entered into only with the free and full consent of the intending spouses.

Sementara itu, Pasal 2 UDHR 1948 juga menyatakan bahwa:

"Everyone is entitled to all the rights and freedoms set forth in this Declaration, without distinction of any kind, such as race, colour, sex, language, religion,
Program Studi Magister Ilmu Hukum Fakultas Hukum Universitas Diponegoro

political or other opinion, national or social origin, property, birth or other status....".

Saat ini, semakin banyak orang yang secara terbuka mengekspresikan orientasi seksual mereka dan menuntut hak-hak mereka. Berkat kinerja para pelaku dan pendukungpendukungnya, penerimaan hak LGBT di seluruh dunia semakin meningkat. Pemerintah di beberapa negara mulai membuat undang-undang yang menerima LGBT serta undang-undang antidiskriminasi, seperti Belanda, Prancis, Denmark, dan Inggris. Belanda merupakan salah satu negara yang berhasil menjadi pelopor di Uni Eropa dalam mempromosikan dan memperjuangkan hak-hak kaum LGBT dengan membuktikan beberapa program yang pro terhadap kaum LGBT yang didukung oleh negaranegara Uni Eropa. belanda juga berhasil meningkatkan penerimaan sosial terhadap LGBT (Saskia, David, 2007).

Globalisasi LGBT terus meningkat, sehingga diperkirakan di tahun-tahun mendatang, akan ada perkembangan isu utama hak-hak LGBT dalam skala global seperti: Pemberantasan penganiayaan berdasarkan orientasi seksual; Perlindungan hukum kaum LGBT dari kebencian dan propaganda kebencian; Hak-hak istimewa yang sama (pernikahan, kemitraan, pengambilan keputusan medis, kehendak, pengasuhan dan adopsi); serta sosialisasi terhadap orang lain yang cenderung homofobia dan heteroseksisme (Subhrajit, 2014). 
Jurnal Law Reform

Volume 14, Nomor 1, Tahun 2018

\section{LGBT dari Perspektif HAM dalam} Lingkup Hukum Indonesia

Hak asasi manusia adalah hak yang melekat pada semua manusia, apa pun kebangsaan kita, tempat tinggal, jenis kelamin, asal kebangsaan atau etnis, warna kulit, agama, bahasa, atau status lainnya. Kita semua sama berhak atas hak asasi manusia kita tanpa diskriminasi. Hak-hak ini semuanya saling terkait, saling bergantung dan tak terpisahkan (UN High Commission for Human Rights, 2018).

Di Indonesia, instrumen hukum yang berlaku serta berperspektif HAM tidaklah sedikit. Sebut saja UUD NRI 1945, UU HAM No. 39/1999, UU Ketenagakerjaan No. 13/2003, UDHR 1948 dan lain sebagainya. Beberapa peraturan perundang-undangan yang berlaku di Indonesia, baik secara eksplisit atau implisit tetap memberikan jaminan akan perlindungan hak-hak asasi manusia.

Indonesia merupakan negara yang mengakui HAM sebagai sesuatu yang eksis dan harus dihormati dan dilindungi. Bab XA UUD NRI 1945 merupakan bab yang secara khusus mengatur tentang HAM di Indonesia secara umum. UUD NRI 1945 secara hierarki merupakan peraturan perundang-undangan tertinggi yang menjadi acuan peraturan perundang-undangan lain di bawahnya, sehingga tidak akan ada peraturan di Indonesia yang tidak mengakui HAM. Selain itu, Indonesia juga mengakui UDHR 1948 yang menjadi instrumen HAM internasional yang diakui oleh bangsa-bangsa di dunia.
Program Studi Magister Ilmu Hukum Fakultas Hukum Universitas Diponegoro

Hal yang menjadi fokus permasalahan adalah bagaimana perlakuan dan sikap bangsa Indonesia, terhadap perilaku seksual menyimpang kaum LGBT yang melakukan perbuatan tersebut dilandasi dengan asas kebebasan HAM. Sebagaimana telah dijelaskan sebelumnya bahwa Indonesia merupakan negara yang masih kental dengan ajaran agama, moral, dan etika yang telah berkembang dan mengakar di seluruh lapisan masyarakatnya. Perilaku "menyimpang" kaum LGBT tentu tidak bisa diterima begitu saja, karena selalu ada alasanalasan mendasar dari masyarakat untuk menolak pelaku dan perilaku seksual menyimpang, baik itu didasari atas ajaran agama maupun budaya.

Meskipun tidak semua masyarakat menolak, sikap "diskriminasi" yang dirasakan oleh kaum LGBT dianggap sebagai pelanggaran HAM. Karena kaum LGBT hidup hampir di setiap bagian belahan dunia, mereka adalah bagian dari anggota masyarakat, etnis, dan agama tertentu. Mereka juga adalah manusia yang harus dihormati haknya, akan tetapi di beberapa negara (termasuk Indonesia) mereka mengalami diskriminasi yang disebabkan oleh identitas dan orientasi seksual (Badgett, Nezhad, Waaldijk, dan Rodgers, 2014).

Komisaris Tinggi Perserikatan BangsaBangsa untuk Hak Asasi Manusia melaporkan bahwa: "hampir di semua wilayah, terdapat orang yang mengalami kekerasan dan diskriminasi karena orientasi seksual atau identitas gender mereka... pelanggaran-pelanggaran HAM yang 
Jurnal Law Reform

Volume 14, Nomor 1, Tahun 2018

terjadi, termasuk - tetapi tidak terbatas pada pembunuhan, perkosaan, dan serangan fisik, penyiksaan, penahanan sewenang-wenang, penolakan hak untuk berkumpul, ekspresi dan informasi, dan diskriminasi dalam pekerjaan, kesehatan dan pendidikan" (UN High Commission for Human Rights, 2011).

UDHR 1948 memang tidak menentukan bahwa orientasi seksual pria harus kepada wanita atau sebaliknya, akan tetapi hal itu tidak secara serta merta berarti bahwa perilaku kaum LGBT harus diperbolehkan dan didukung. UDHR 1948 juga mengatur pembatasan, dalam Pasal 29 (2) dinyatakan bahwa:

In the exercise of his rights and freedoms, everyone shall be subject only to such limitations as are determined by law solely for the purpose of securing due recognition and respect for the rights and freedoms of others and of meeting the just requirements of morality, public order and the general welfare in a democratic society (UDHR 1948).

Sementara itu, UDHR juga menjamin hak setiap orang untuk percaya pada ajaran agamanya, dan mempraktekkan ajaran agama itu dengan baik. Seni. 18 dari UDHR 1948 menyatakan bahwa:

Everyone has the right to freedom of thought, conscience and religion; this right includes freedom to change his religion or belief, and freedom, either alone or in community with others and in public or private, to manifest his religion or belief in teaching, practice, worship and observance.

Sama halnya di dalam UU nasional, Pasal 28J (2) UUD NRI 1945, Pasal 69 (1), dan 73 UU
Program Studi Magister Ilmu Hukum Fakultas Hukum Universitas Diponegoro

HAM No. 39/1999, telah ditentukan pembatasan yang intinya bahwa setiap orang yang memiliki HAM juga harus menghormati HAM orang lain, menghormati pembatasan yang ditentukan oleh UU, memenuhi persyaratan moral, etika, tata tertib kehidupan masyarakat, berbangsa dan bernegara, nilai-nilai agama, serta menjaga keamanan dan ketertiban umum masyarakat demokratis.

Dalam peraturan perundang-undangan telah ditetapkan pembatasan bahwasanya pernikahan yang diakui adalah pernikahan yang dilangsungkan secara sah (Pasal 28B UUD NRI 1945), pernikahan dianggap sah jika dilaksanakan berdasarkan ketentuan agama, dan pernikahan adalah dilakukan oleh seorang pria dan wanita (UU Perkawinan No. 1/1974). Seandainyapun kaum LGBT melakukan perilaku seksual menyimpang bukan untuk berkeluarga/menikah, dalil penolakan justru semakin menguat. Secara moral, etika, nilai agama, dan ketertiban masyarakat, hubungan seksual tanpa menikah antara lelaki dan perempuan tidak dibenarkan oleh masyarakat, apalagi jika ditambah dengan perilaku seksual tersebut menyimpang dari fitrahnya.

\section{LGBT dari Perspektif Agama dalam Lingkup Hukum Indonesia}

Kata 'agama' berasal berakar dari Bahasa Latin 'Religio' yang berarti ikatan antara kemanusiaan dengan suatu kekuatan yang lebih besar dari manusia itu sendiri. Para ilmuan mengidentifikasi setidaknya terdapat desain 
Jurnal Law Reform

Volume 14, Nomor 1, Tahun 2018

historis dari istilah tersebut: 1) kekuatan supernatural yang memotivasi dan diakui oleh manusia; 2) perasaan dari dalam individu yang meyakini kekuatan itu; 3) tindakan ritual yang dilakukan sehubungan dengan kekuasaan itu (Peter, 2000).

Sila ke-1 dari Dasar Negara RI menyebutkan bahwa Indonesia mengakui adanya 'Tuhan', manifestasi nyata dari pengakuan terhadap Tuhan adalah dengan menaati perintah dan larangan-Nya yang termaktub dalam kitab suci dan ajaran agama. Pasal 28E ayat (1) Undang-Undang Dasar Tahun 1945 ("UUD 1945”) mengatur bahwa: "Setiap orang bebas memeluk agama dan beribadat menurut agamanya...". Pasal 28E ayat (2) UUD 1945 juga mengatur bahwa setiap orang berhak atas kebebasan meyakini kepercayaan. Selain itu dalam Pasal 28I ayat (1) UUD 1945 juga mengatur bahwa hak untuk beragama merupakan hak asasi manusia. Selanjutnya Pasal 29 ayat (2) UUD 1945 juga menyatakan bahwa Negara menjamin kemerdekaan tiap-tiap penduduknya untuk memeluk agama.

Agama yang diakui di Indonesia tidak membolehkan perilaku seksual yang menyimpang, sebagaimana disebutkan dalam Alquran: "Sesungguhnya kalian mendatangi lelaki untuk melepaskan nafsu kalian (kepada mereka), bukan kepada wanita, maka kalian ini adalah kaum yang melampaui batas" (Q.S. AlA'raaf: 81) (Sayyid, 2002). Dalam Islam, LGBT adalah tindakan yang sangat hina, hal itu
Program Studi Magister Ilmu Hukum Fakultas Hukum Universitas Diponegoro

ditunjukkan dalam sebuah surat "Luth", dalam surat tersebut, diceritakan bagaimana Allah marah besar dan menghukum sekelompok orang yang melakukan tindakan homoseksual. Alkitab juga menyatakan dengan jelas bahwa Allah merancang bahwa seks dilakukan hanya antara pria dan wanita, dan hanya dalam ikatan perkawinan (Kejadian 1:27, 28; Imamat 18:22; Amsal 5:18, 19), Alkitab mengutuk perzinahan, yang termasuk perilaku homoseksual serta heteroseksual terlarang (Gal 5: 19-21).

Hukum menjamin hak setiap orang untuk beragama dan menjalankan kewajiban sesuai tuntunan agamanya. Ajaran agama Islam contohnya, seorang muslim bukan diperintahkan untuk melaksanakan kewajiban saja tetapi juga mencegah kemungkaran. Jika terjadi sebuah penyimpangan terhadap ajaran agama (LGBT) terutama jika dilakukan oleh yang juga beragama Islam, maka sesuatu yang wajar jika mereka menolak pelaku dan perilaku seksual menyimpang LGBT. Berdasarkan pandangan agama, LGBT merupakan sebuah penyimpangan dari kehendak Tuhan, bahwa seharusnya lelaki berpasangan dengan wanita dan begitu juga sebaliknya.

Perundang-undangan menetapkan pembatasan dalam Pasal 28B (1) UUD 1945:

"Setiap orang berhak membentuk keluarga dan melanjutkan keturunan melalui perkawinan yang sah".

Di Indonesia sebuah pernikahan akan dianggap sah jika mematuhi ketentuan agama, dan pernikahan dilakukan oleh seorang pria dan 
Jurnal Law Reform

Volume 14, Nomor 1, Tahun 2018

seorang wanita, Pasal 1 dan 2 dari UndangUndang No. 1/1974 tentang Perkawinan menyatakan bahwa:

"Perkawinan ialah ikatan lahir bathin antara seorang pria dengan seorang wanita sebagai suami isteri dengan tujuan membentuk keluarga (rumah tangga) yang bahagia dan kekal berdasarkan Ketuhanan Yang Maha esa" "Perkawinan adalah sah, apabila dilakukan menurut hukum masing-masing agamanya dan kepercayaannya itu".

Berangkat dari ketentuan perundangundangan di atas, jika perilaku menyimpang LGBT tidak dimaksudkan untuk menikah, justru akan membuat dalil penolakan menjadi lebih kuat. Sebab, berdasarkan moralitas, etika, agama, nilai-nilai dan tatanan masyarakat, hubungan seksual tanpa menikah antara pria dan wanita tidak diperbolehkan dan dianggap perbuatan asusila, terlebih lagi jika hal itu dilakukan dengan perilaku seksual menyimpang.

Pelaku LGBT akan mendapatkan banyak kerugian, sebab sistem pemerintahan, budaya, dan lingkungan masyarakat Indonesia tidak disiapkan untuk kaum dengan perilaku seksual menyimpang (Serra, 2013). Sehingga, kaum LGBT menjadi rentan terhadap berbagai bentuk masalah sosial, seperti kriminalisasi, kekerasan, bullying, penolakan, dan lain sebagainya (Subhrajit, 2014).

Pendapat penolakan terhadap pelaku dan perilaku LGBT juga dilontarkan oleh beberapa tokoh agama dan politik di Indonesia:

Anwar Abbas dari Muhammadiyah, menjelaskan bahwa LGBT adalah
Program Studi Magister Ilmu Hukum Fakultas Hukum Universitas Diponegoro

penyakit yang harus disembuhkan, dan merupakan penyimpangan terhadap norma agama dan hukum alam. Menurut Abbas, LGBT tidak ada hubungannya dengan isu hak asasi manusia, oleh karena itu, negara harus membantu menyembuhkan mereka, tidak mentolerirnya atau bahkan melegalkan keinginan mereka. Isu LGBT juga telah ditolak dengan tegas oleh Majelis Ulama Indonesia (Penasihat Ulama Islam / MUI). Menurut Makruf Amin, pemerintah dan masyarakat seharusnya tidak memberikan kesempatan legalisasi perkawinan sesama jenis karena akan membahayakan generasi penerus. Apalagi, Amin, menekankan bahwa Indonesia memiliki mayoritas populasi Muslim, menyiratkan bahwa menjadi LGBT tidak semestinya dengan menjadi seorang Muslim. Ketua Komisi Fatwa MUI, AF Hasanuddin, lebih eksplisit dalam pandangannya yang menunjukkan bahwa LGBT adalah tindakan ilegal, kejahatan keji dan dosa berat, dan dapat dihukum dengan hukuman mati. Ketua Komisi Perlindungan Anak Indonesia (KPAI), Asrorun Niam, juga menyatakan bahwa sodomi lebih buruk daripada perzinahan dan seks di luar nikah, dan dihukum dengan hukuman keras. Said Aqil Siradj dari Nahdatul Ulama, menyatakan bahwa konsensus antara ahli hukum Islam sepakat bahwa seksualitas LGBT dilarang. Mengutip penjelasan dari Fakhruddin al-Razi, seorang komentator Islam ahli, Siradj, menyatakan bahwa perilaku homoseksual adalah tindakan keji, disebut sebagai al-fakhisyah (dosa besar) yang menjijikkan dan bertentangan dengan sifat manusia" (Muthmainnah, 2016).

Seorang Pendeta Katolik, Pastor Benny Susetyo, menegaskan bahwa sejak awal Gereja Katolik menolak LGBT (lesbian, gay, biseksual, dan transgender) dengan tegas, "semua agama tidak dapat menerima perilaku seksual yang menyimpang". Benny juga menyatakan 
Jurnal Law Reform

Volume 14, Nomor 1, Tahun 2018

bahwa "Gereja Katolik, Vatikan dan Paus, sejak awal menyatakan tidak akan ada pernikahan yang melanggar sifat manusia yang diciptakan oleh Tuhan berpasangan pada pria dan wanita" (Srihandriatmo, 2016).

Pandangan dari sisi agama, yang kebebasan beribadah dan menjalankan perintah Tuhan-nya dijamin oleh hukum nasional, LGBT merupakan perilaku yang tidak dapat diterima. Argumen penolakan berkutat pada dalil kitab suci dan ajaran agama yang tidak dapat "ditawar" karena merupakan perintah Tuhan.

\section{Titik Pertautan}

Permasalahan berada pada dilema antara perlindungan HAM kaum LGBT dan penghormatan ajaran agama, di mana keduanya ditetapkan dan dijamin eksistensinya oleh hukum nasional dan internasional yang berlaku di Indonesia. Oleh sebab itu, penulis berpikiran bahwa, sudah menjadi kewajiban negara untuk melindungi kaum LGBT dari segala bentuk pelanggaran HAM yang terjadi. Mereka kaum LGBT juga adalah manusia yang berhak mendapatkan apa yang orang lain juga dapatkan sebagai manusia, akan tetapi perlu diperhatikan bahwa perlindungan HAM atas mereka juga memiliki batasan sebagaimana yang sudah ditentukan.

Sebenarnya di Indonesia, perlakuan terhadap kaum LGBT masih dapat dikatakan "lebih soft" dibandingkan dengan negara lain yang juga menolak LGBT. Indonesia belum secara tegas menyatakan bahwa perilaku LGBT adalah tindak kriminal yang dapat dihukum pidana, lain
Program Studi Magister Ilmu Hukum Fakultas Hukum Universitas Diponegoro

halnya dengan Iran misalnya, di sana pelaku LGBT dapat dikenai hukuman pidana mati (Bevilacqua, Harper, Kent, 2014).

Perlindungan HAM atas kaum LGBT harus ditegakkan dalam hal jika mereka mengalami diskriminasi, bullying, kekerasan, dan segala bentuk pelanggaran HAM lainnya. Sebagaimana dilaporkan oleh Komnas HAM pada 2015, bahwa Komunitas LGBT mengalami kesulitan dalam pemenuhan hak atas kesehatan, hak atas pekerjaan, hak untuk mendapatkan perlakuan hukum yang adil, dan hak atas kebebasan berekspresi (Komnas HAM, 2016). Berdasarkan laporan di atas secara objektif dapat dilihat bahwa kelompok LGBT memang mengalami pelanggaran HAM dalam hal hak mengakses fasilitas kesehatan, mendapatkan pekerjaan, dan hukum yang adil. Baik berdasarkan hukum, agama, dan HAM, setiap orang harus memiliki hak yang sama untuk hal-hal tersebut dan diperlakukan secara adil, tanpa harus dipastikan terlebih dahulu subjek merupakan LGBT atau tidak. Akan tetapi, mengenai kebebasan berekspresi, kita harus jeli kebebasan seperti apa yang diinginkan, seperti apa bentuk ekspresi yang dilakukan, dan apakah hak bebas berekspresi tersebut melanggar hak orang lain, norma agama, budaya, dan ketertiban umum setempat.

Perlindungan HAM kaum LGBT bukan berarti menuruti segala kemauan dan tuntutan mereka, pemerintah harus jeli memilah bahwa tidak semua tuntutan mereka murni berasaskan pada HAM, dari beberapa faktor ada tuntutan 
Jurnal Law Reform

Volume 14, Nomor 1, Tahun 2018

yang menginginkan terwujudnya kehendak tanpa memikirkan HAM masyarakat di sekitar mereka.

Secara hukum, HAM memang diakui, dihormati, dan dilindungi di Indonesia. Akan tetapi bukan berarti bahwa setiap kemauan dapat dilaksanakan secara bebas. Terdapat pembatasan-pembatasan yang ditetapkan UU, ajaran moral, etika masyarakat, dan nilai agama yang menegaskan bahwa setiap manusia di samping memiliki hak asasi manusia untuk dipenuhi hak asasinya, mereka juga memiliki kewajiban asasi manusia untuk menghormati hak asasi orang lain dan masyarakat sekitar di mana mereka berada. Oleh sebab itu, Penulis sangat setuju dengan pendapat bahwa "HAM itu bersifat universal tetapi memiliki struktur sosialnya sendiri".

Pendekatan terhadap hak asasi manusia tidak dapat dilakukan dengan berpegang pada sifat universal atau khusus saja, tetapi harus memasukkan aspek-aspek penting dari kedua sudut pandang. Standar yang sifatnya umum harus dimunculkan, agar memiliki visi dan misi yang seragam dalam penegakan HAM, dan pada saat yang sama diiringi nilai agama dan budaya (Hoang, 2009) yang hidup dan telah lama dianut oleh setempat. Contohnya, tradisi ketimuran memandang hak asasi manusia sebagai sesuatu yang menjadi milik masyarakat, bukan sebagai hak absolut dari individu. Tradisi ini yang kemudian mendorong seseorang selain memenuhi hak pribadinya, dia juga akan memikirkan hak orang lain. Pemikiran ini
Program Studi Magister Ilmu Hukum Fakultas Hukum Universitas Diponegoro

kemudian memunculkan sikap toleransi terhadap kepentingan bersama.

Universalitas ide-ide LGBT global bukan tanpa kritik, karena pada tingkat teoritis kita diharuskan untuk mengecek ide-ide atau fenomena universal berulang kali. Hal ini bukan untuk menunjukkan bahwa universalitas selalu salah, tetapi akan lebih baik jika berasumsi bahwa universalitas selalu dibangun untuk kepentingan dan/atau tujuan tertentu. Sebaliknya, kebenaran itu bersifat lokal, mereka kontekstual, dan terikat oleh budaya, historis, serta waktu. Oleh karena itu, dalam menilai apakah LGBT dapat dianggap sebagai konsep yang dapat diterima di suatu tempat, maka harus dilakukan pemeriksaan mendalam apakah budaya masyarakat di tempat tersebut bersedia menerima perilaku tersebut.

Langkah selanjutnya, keadaan tidak boleh dibiarkan begitu saja, harus ada upaya "penyembuhan dan pemulihan" agar para kaum LGBT tidak lagi menjadi korban pelanggaran HAM dan masyarakat merasa dihormati keyakinannya. Jika memang faktor penyebab permasalahan adalah perilaku seksual yang menyimpang maka jalan keluarnya bukanlah melegalkan perilaku tersebut akan tetapi diarahkan pada perilaku yang "normal".

Sebagai kelompok minoritas dengan perilaku yang berada di luar kebiasaan yang dianggap "normal" oleh kelompok mayoritas, sudah sepantasnya kaum minoritas tersebutlah yang harus menyesuaikan diri, bukan memaksakan kehendak kepada kaum mayoritas. 
Jurnal Law Reform

Volume 14, Nomor 1, Tahun 2018

Perilaku "abnormal"-lah yang harus diperbaiki bukan perilaku "normal" yang diserang dengan dalil "intoleran dan tidak berperspektif HAM".

Perlindungan terhadap mereka yang sudah menjadi kaum LGBT terus ditegakkan disertai dengan treatment penyembuhan dan pemulihan, sehingga hak-hak kaum LGBT sebagai manusia dapat terpenuhi, bersamaan dengan penghormatan terhadap keyakinan agama yang juga tercapai. Oleh sebab itu, untuk kasus di Indonesia, dibutuhkan aksi pemahaman mendalam yang berfokus pada beberapa target/subjek, yaitu:

\section{1) Pelaku-Pendukung LGBT}

Baik pelaku-pendukung LGBT harus memahami secara mendalam hakikat dari HAM, serta memahami bahwa semua orang juga memiliki HAM yang harus dihormati. Di Indonesia, baik itu ditinjau dari perspektif hukum, agama, dan HAM, perilaku LGBT yang menyukai dan berorientasi seksual kepada sesama jenis tidak dapat dibenarkan. Hal itu disebabkan HAM yang selalu digadang-gadangkan dan dijadikan dalil pembenaran memiliki batasan UU, norma agama, etika, dan budaya masyarakat setempat. Tepat jika HAM dijadikan alat untuk menuntut perlakuan yang adil, dan tidak tepat jika dijadikan alat memaksakan kehendak pembenaran terhadap perilaku seksual menyimpang di tengah-tengah masyarakat yang religius dan berbudaya heteroseksisme.
Program Studi Magister Ilmu Hukum Fakultas Hukum Universitas Diponegoro

\section{2) Penolak LGBT}

Para penolak LGBT harus memahami bahwa setiap orang memiliki HAM termasuk kelompok LGBT. Penolakan terhadap perilaku seksual menyimpang sah dilakukan berdasarkan Asas Ketuhanan Negara Indonesia, norma agama, dan hukum yang melindungi keberagamaan masyarakat Indonesia. Akan tetapi, perlu dibatasi bahwa penolakan tersebut tidak lantas melegalkan perbuatan-perbuatan diskriminatif yang melanggar hukum dan HAM kelompok LGBT dalam hal-hal umum (kesehatan, pendidikan, pekerjaan, dsb).

\section{3) Pemerintah}

Pemerintah harus mampu menerapkan konsep "Ham Universal dan Memiliki Struktur Sosialnya Sendiri". Menghadapi isu tuntutan HAM dan pelanggaran HAM kelompok LGBT, tentu juga harus memerhatikan kepentingan masyarakat Indonesia secara luas. Di samping terus mengadvokasi dan menjamin perlindungan terhadap pelanggaran HAM atas kelompok LGBT, juga menerapkan batasan pemenuhan HAM yang diminta. Dapat dikatakan masyarakat Indonesia mayoritas heteroseksisme, dan tidak dpat diabaikan adanya kelompok LGBT sebagai minoritas. Oleh sebab itu perlu dicanangkan program "LGBT recovery treatment", program yang melibatkan berbagai instansi yang berkompeten baik dari ibidang kesehatan, psikologi, dan keagamaan yang bersinergi untuk memulihkan perilaku seksual yang menyimpang. Terakhir, meski masih dipandang ekstrim, 
Jurnal Law Reform

Volume 14, Nomor 1, Tahun 2018

terdapat kemungkinan untuk membentuk peraturan perundang-undangan yang melarang LGBT.

\section{4) Akademisi}

LGBT bukanlah fenomena ajaib yang tidak memiliki penjelasan ilmiah, banyak penelitian telah dilakukan terhadap isu LGBT. Meskipun sampai saat ini belum ada kesamaan hasil, setidaknya dapat memberikan gambaran fenomena LGBT, baik dari sisi penyebab, pemicu, dan pendukung munculnya perilaku seksual menyimpang. Oleh sebab itu perlu dibentuk pusat kajian LGBT yang melibatkan banyak peneliti dari berbagai bidang keilmuan. Dari hasil penelitian diharapkan terbentuk formula bagaimana cara mencegah dan menanggulangi perilaku seks menyimpang.

\section{Kesimpulan dan saran \\ 1. Kesimpulan}

Hukum Indonesia mengakui penegakan HAM yang disertai pembatasan bahwa setiap orang yang memiliki HAM juga harus menghormati HAM orang lain, menghormati pembatasan yang ditentukan oleh UU, memenuhi persyaratan moral, etika, tata tertib kehidupan masyarakat, berbangsa dan bernegara, nilai-nilai agama, serta menjaga keamanan dan ketertiban umum masyarakat demokratis.

Hukum menjamin kebebasan beragama dan menjalankan kewajiban sesuai tuntunan agamanya. Sehingga dari sisi agama, yang kebebasan beribadah dan menjalankan perintah Tuhannya dijamin oleh hukum nasional, LGBT
Program Studi Magister Ilmu Hukum Fakultas Hukum Universitas Diponegoro

merupakan perilaku yang tidak dapat diterima. Argumen penolakan berbasis pada dalil kitab suci dan ajaran agama yang tidak dapat "ditawar" karena merupakan perintah Tuhan.

Perlindungan HAM atas kaum LGBT harus ditegakkan dengan menerapkan konsep "HAM Universal dan Memiliki Struktur Sosialnya Sendiri". Kelompok LGBT wajib dilindungi dari diskriminasi, bullying, kekerasan, dan segala bentuk pelanggaran HAM lainnya. Sementara itu, penghormatan atas keyakinan dan ajaran agama harus dijaga, sehingga diperlukan upaya "penyembuhan dan pemulihan" perilaku seks menyimpang kelompok LGBT yang melibatkan banyak pihak mulai dari pelaku LGBT, pendukung, penolak, pemerintah, dan akademisi. Kesemua aksi yang dilakukan focus bertujuan agar kelompok LGBT tidak lagi menjadi korban pelanggaran HAM dan masyarakat Indonesia merasa dihormati keyakinannya.

\section{Saran}

Indonesia sebagai negara hukum dan negara yang mengakui eksistensi agama, dalam menghadapi fenomena globalisasi LGBT harus bersikap tegas untuk menolak legalisasi praktek perilaku seksual yang menyimpang (perbuatanperbuatan yang mengindikasikan orientasi seksual pada sesama jenis). Oleh sebab itu, negara tetap harus melindungi kaum LGBT dari segala bentuk pelanggaran HAM yang terjadi. Selain itu, perlu diperhatikan bahwa penegakan HAM atas mereka juga memiliki batasan 
Jurnal Law Reform

Volume 14, Nomor 1, Tahun 2018

menghormati HAM orang lain, norma agama, etika, dan budaya masyarakat di sekitar mereka.

Di samping itu, diperlukan langkah-langkah konkrit sebagai upaya 'penyembuhan dan pemulihan' kaum LGBT. Salah satunya adalah dengan memfasilitasi proses penyembuhan dan pemulihan tersebut seperti dengan mendirikan tempat-tempat yang dapat dijadikan basis 'healing centre'. Tempat di mana kaum LGBT akan mendapatkan bimbingan dari berbagai ahli dengan berbagai metode penyembuhan (terapi psikologi, terapi behavior, bimbingan spiritual, agama, dII). Diharapkan dengan memasukan seseorang ke dalam lingkungan yang lebih 'bersih dan baik', dapat membentuk ulang perilakunya yang menyimpang ke arah yang benar.

\section{Daftar Pustaka}

APA (American Psychological Association).

(2015). Definitions Related to Sexual Orientation and Gender Diversity in APA Documents. $\quad$ Retrieved from https://www.apa.org/pi/lgbt/resources/sex uality-definitions.pdf, diakses pada 26 Juli 2017.

Bevilacqua, Catherine., Harper, Elizabeth., Kent, Catherine. (2014).

Sexual Orientation and Gender Identity: Iran's International Human Rights Obligations, In Proceedings of Legal Research Series on Human Rights in Iran Units, (pp. 2-18). Iran : University of Essex.
Program Studi Magister Ilmu Hukum Fakultas Hukum Universitas Diponegoro

Subhrajit, C. (2014). Problems Faced by LGBT

People in the Mainstream Society: Some Recommendations, International J ournal of Interdisciplinary and Multidisciplinary Studies (IJ IMS), Vol 1 (No.5), pp. 317331.

Crews, Douglas., \& Crawford, Marcus. (2015).

Exploring the Role of Being Out on a Queer Person's Self-Compassion. J ournal of Gay \& Lesbian Social Services Vol. 27 (No. 2), pp. 172-186.

Gardbaum, S. (2008). Human Rights as International Constitutional Rights. The European Journal of International Law Vol 19, pp. 749-750.

Onapajo, Hakeem., \& Isike, Cristhoper. (2016).

The Global Politics

of Gay Rights: The Straining Relations between the West and Africa. J ournal of Global Analysis, Vol. 6 (No. 1, January), pp. 22-34.

Hill, Peter C., et.al. (2000). Conceptualizing

Religion and Spirituality: Points of Commonality, Points of Departure, Journal for the Theory of Social Behaviour Vol. 30, p. 52.

Keuzenkamp, Saskia., \& Bos, David. (2007) Out

in The Netherlands: Acceptance of Homosexuality in the Netherlands, Belanda : The Netherlands Institute for Social Research. 
Jurnal Law Reform

Volume 14, Nomor 1, Tahun 2018

Nurkhoiron, M. (2016). Komnas HAM, Siaran

Pers Komnas HAM tentang LGBT, Jakarta.

M.V.L, Badgett., S, Nezhad., C, Waaldijk.,

Y.V.D.M, Rodgers. (2014). The

Relationship between LGBT Inclusion and Economic Development, In Proceedings of An Analysis of Emerging Economies (pp. 1-7), The William Institute : USAID.

Malau, S. (2016). 'Romo Benny : Sejak Awal Sikap Gereja Katolik Tegas Tolak LGBT'. Retrieved from http://m.tribunnews.com/ nasional/2016/02/17/romo-bennysejak-awal-sikap-gereja-katolik-tegastolak-lgbt, diakses pada 26 Juli 2017.

Menara Pengawal. (2017). Apa Pandangan

Alkitab tentang Homoseksualitas? Retrieved from https://wol.jw.org/id/wol/ d/r25//p-in/1102011149, diakses pada 26 Juli 2017.

Serra, N.E. (2013). Queering International Human Rights : LGBT Access to Domestic Violence Remedies, J ournal of Gender, Social Policy, \& the Law, Vol. 21 (No. 3), pp. 583-607.

Nghia, Hoang Van. (2009). The "Asian Values"

Perspective of Human Rights : A Challenge to Universal Human Rights. Retrieved from http://ssrn.com/ abstract=1405436, diakses pada 26 Juli 2017.
Program Studi Magister IImu Hukum Fakultas Hukum Universitas Diponegoro

Encarnacion, O.G. (2014). Gay Rights : Why

Democracy Matters, Journal of Democracy, Vol. 25 (No. 3, July), pp. 90102.

Quthb, Sayyid. (2002). Tafsir Fi Zhilalil-Q uran Di bawah Naungan Al-Qur'an (Vol. 4), diterjemahkan oleh : As'ad Yasin, et.al, $1^{\text {st }}$ printing, Jakarta: Gema Insani Press.

Sinyo. (2014). Anakku BertanyaTentang LGBT. Jakarta : PT. Elex Media Komputindo.

Winurini, S. (2016). Memaknai Perilaku LGBT di Indonesia (Tinjauan Psikologi Abnormal), Info Singkat Kesejahteraan Sosial Vol. VIII (No. 05, Maret), p. 11.

UN Offfice of The High Commissioner for HumanRights. Retrieved from https://www.ohchr.org/documents/issues/ discrimination/a.hrc.19.41_english.pdf, diakses pada 26 Juli 2017.

UN Office of The High Commissioner for Human Rights, What are Human Rights. Retrieved from http://www.ohchr.org/EN/ Issues/Pages/WhatareHumanRights.aspx , diakses pada 26 Juli 2017.

Muthmainnah, Y. (2016). LGBT Human Rights in Indonesian Policies, Indonesian Feminist J ournal, Vol. 4 (No. 1, March), pp. 13-22. 